\title{
Methodology Focused on Identifying Variables Necessary to Develop Logistics Clusters
}

\author{
Cristiano Farias Almeida ${ }^{1}$, Yaeko Yamashita ${ }^{2}$, Mario Cools ${ }^{3}$, Jean Marchal ${ }^{3} \&$ Bernard Piette $^{4}$ \\ ${ }^{1}$ Graduate Program Project and City, Federal University of Goias, Goiânia, Brazil \\ ${ }^{2}$ Graduate Program of the Faculty of Architecture \& Urbanism, Brasília University, Brasília, Brazil \\ 3 Urban and Environmental Engineering Department, Center for Transport, Mobility \& Logistics, Liège \\ University, Liège, Belgium \\ ${ }^{4}$ Logistics in Wallonia, Liège, Belgium \\ Correspondence: Cristiano Farias Almeida, Graduate Program Project and City, Federal University of Goias, \\ Goiânia, Brazil. Tel: 55-91-9-9132-9191. E-mail: cristianofarias@ufg.br
}

Received: March 27, 2021

doi:10.5539/jsd.v14n3p147
Accepted: April 20, $2021 \quad$ Online Published: April 29, 2021

URL: https://doi.org/10.5539/jsd.v14n3p147

\begin{abstract}
Several scholars have addressed the locational factors necessary for the best installation of industries or services; among them, one finds the costs with transportation of products and raw materials, labor-related costs, benefits deriving from the agglomeration of companies, as well as place-environment associations. Some agglomeration types stand out in this context, each one of them has its specific features, although they share the same goal. The agglomeration of companies is an increasingly frequent trend observed in production centers. Companies belonging to the same production chain remain close to each other in order to reduce costs with product transportation, storage and distribution processes. Consequently, they get to optimize their processes and increase their profits. The proximity between companies belonging to the same branch increases competitiveness between them. In addition, there is significant presence of skilled labor in these regions, a fact that favors logistics operations such as the transportation of inputs needed to enable companies' production, and cost reduction. Thus, the aim of the present research is to create a methodology capable of identifying the variables necessary to develop a logistics cluster based on concepts such as productive economic agglomerations, by taking into consideration aspects addressed in a survey conducted with key cluster policy-development actors. Moreover, Interpretive Structural Modelling (ISM) was used to create an ontology to help better understanding the association among all variables necessary to structure logistics clusters.
\end{abstract}

Keywords: logistics cluster, productive agglomerations, ontology, Interpretive Structural Modeling

\section{Introduction}

Any economic model is supposed to admit that production factors are scarce and limited when it comes to consumers' desires. According to such a logic, choosing one good implies being deprived of another one. Thus, societies should make choices in order to fulfill their desires (Lipsey \& Chystal, 2011).

A series of facilities such as hospitals, roads, ports, warehouses, among others, stand out among the "consumption desires of a given society". The decision-making process should focus on achieving the greatest benefits by using the lowest amount of resources possible (Lipsey \& Chystal, 2011). This cost-benefit ratio could be seen as investment efficiency. A series of factors can influence investment efficiency; spatial factors are variables of paramount importance (De Souza, 1981; Rodrigue et. al., 2006).

Several scholars have addressed locational factors necessary for the best installation of industries or services; among them, one finds costs with transportation of products, labor-related costs, benefits deriving from the agglomeration of companies, as well as place-environment associations (De Souza, 1981; Brusco, 1990).

The agglomeration of companies is an increasingly frequent trend observed in production centers. Companies belonging to the same production chain remain close to each other in order to reduce costs with product transportation, storage and distribution processes, as well as to optimize their processes and increase their profit (Sheffi, 2012). 
The proximity between companies belonging to the same branch increases competitiveness between them. In addition, there is significant presence of skilled labor in these regions, a fact that favors logistics operations, such as the transportation of inputs needed to enable companies' production and cost reduction (Keller, 2008; Becattini, 1990). Industrial agglomerations can be formed based on the proximity of companies; such a phenomenon is increasingly gaining room. At global scale, important examples of it are the Silicon Valley in California, Competitive Poles in Walloon Region and Logistics Platforms in Zaragoza. Logistics field has also been the driving force of cluster formation processes. Several terms, such as clusters, have been used to describe industrial agglomeration.

Clusters can ensure that different interests are taken into account and that multiple groups can contribute to find solutions. Clusters are also used in research and development initiatives (Oxford Research, 2012). Cluster formations, as well as the formation of productive and innovation agglomerations - which is a topic mostly associated with regional and industrial development, so far - should also be managed by agents linked to cluster development policies. Nevertheless, identifying the variables necessary to implement clusters is the first - and perhaps, the most important - task to be fulfilled in the cluster development policy context.

Therefore, the aim of the current research was to create a methodology capable of identifying the variables necessary to develop a logistics cluster, based on concepts such as productive economic agglomerations, by taking into consideration aspects addressed in a survey conducted with key cluster policy-development actors. Moreover, the present study used tools such as Interpretive Structural Modeling (ISM) to help better understanding the association among all variables necessary to develop logistic clusters.

\section{Literature Review}

Being familiar with some concepts and with the way they relate to each other, as well as understanding the history of thought has been developed about the subject, are of paramount importance to help building a theoretical model. Thus, this topic covers the main concepts associated with cluster development and logistics cluster. Ontology and Interpretive Structural Modeling (ISM) have provided the theoretical basis for the herein developed methodology (Figure 1).

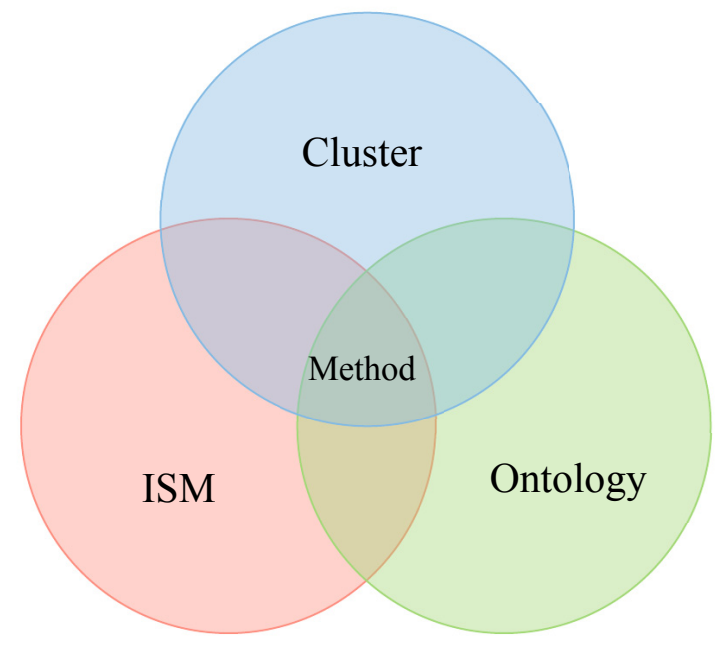

Figure 1. References used to develop the methodology

\subsection{What is a Cluster?}

Clusters are geographic concentrations of interconnected companies and institutions in a particular field (Porter, 2000). Clusters encompass an array of linked industries and other important entities to competition. They include, for example, suppliers of specialized inputs such as components, machinery, services and specialized infrastructure providers (Porter, 1998). If one takes into consideration such a subject, several commonly accepted cluster features stand out (Davis et. al, 2006), namely:

- $\quad$ Firms are linked to each other through trade and non-trade relationships.

- Interlinked firms are geographically close to each other, and 
- Clusters encompass a mix of public and private organizations, such as research institutions, suppliers, and business service providers, which make available specialized skills and valuable infrastructure for the cluster.

\subsubsection{Cluster and Competitiveness}

Modern competition depends on productivity, rather than on access to inputs or on the scale of individual companies. Productivity rests on how companies compete to each other, rather than on the specific fields they compete in. Companies can be highly productive in any industry - shoes, agriculture, or semiconductors - when they adopted sophisticated methods, use advanced technology, as well as offer unique products and services. All industries can use advanced technology and be knowledge intensive (Porter, 1998). Thus, clusters can help improving productivity since they provide geographic area, a set of facilities, integration among firms, organization and a group of services necessary to increase companies' productivity, and to improve value chains.

According to Porter (2000), clusters affect competition in three broad ways: first, they increase the productivity of companies based in the area; second, they drive the direction and pace of innovation, which underpins productivity increase in the future; and third, they encourage the formation of new businesses, and it expands and strengthens the clusters themselves.

\subsubsection{Cluster and Economic Policy}

Clusters provide the tool to organize the thinking about different policy fields that go beyond the common needs of the entire economy (Porter, 2000). Cluster-based thinking can help setting priorities and guiding policies focused on promoting science and technology, education and training, exports and foreign investments, as well as a wide variety of other fields. Established or emerging clusters are the best chance of a given location to attract foreign investments and to promote exports processes (Porter, 2000).

Therefore, clusters' orientation highlights the fact that more government sectors that are often acknowledged can influence competitiveness, mainly within the government itself. Cluster theory makes the impacts of policies on competitive position much clearer and more operational. Effective solutions often require different government sectors to collaborate with each other (Porter, 2000).

Thus, governments at all levels have adopted the concept of cluster as tool to promote national and regional competitiveness, innovation and growth (OECD, 1999; OECD, 2002), since cluster development enables facing challenges posed by increased international competition and by the growing importance of innovation for knowledge about economy.

\subsubsection{Cluster Development Importance}

The economic dynamism of cities and the support to programs and public policies by agencies accountable for urban development processes are a matter of fundamental importance for the action of these agencies. There is no way to put urban development policies into practice without the economic dynamism of cities.

The strength and advantage of clusters lie on the proximity between similar companies and on their integration into several value-chain links. Information and knowledge sharing, efficient and specialized common supply basis, professional-skill development and competence pools are the main driving forces of this strength. Recently, sharing investments in innovation were added to the list of agglomeration economies.

Clusters enable the vertical and horizontal integration of firms. Direct and close negotiation relationships among firms from different links, although belonging to the same value-chain (vertical integration), are completed by the common use of services and facilities by firms belonging to the same branch (horizontal integration) (Davis et. al., 2006; Sheffi, 2012).

\subsubsection{Logistics Clusters}

According to Sheffi (2012), logistics clusters are agglomerations of firms and operations of several types. Such clusters include firms that provide logistics services to companies, such as truck maintenance operations, software providers, specialized law firms, international financial service providers, among others.

Many names have been used to describe several initiatives such as village logistics, logistics park, logistics center, inland or dry port, among others. All these names work according to the principle of production and appropriation of value aggregation based on location sharing, on access to infrastructure and connectivity, as well as on human capital availability and innovation.

According to Sheffi (2012), logistic clusters mainly comprise three company types, namely: (i) logistics service providers, such as transportation carriers, warehousemen, forwarders, third party logistics companies (3PLs), customs brokers, as well as specialized consulting and IT providers; (ii) companies with logistics-intensive 
operations, where value added operations may be smaller than logistics-related activities, such as distributors, and light manufacturing and kitting companies; and (iii) logistics operations of industrial firms, such as retailer distribution operations and after-market part suppliers.

Several advantages of industrial clusters can be found in logistics clusters, which have several unique features that reinforce their formation and advantages. These advantages can be divided into two categories, namely: operational advantages associated with transportation and the ones associated with assets' sharing among companies. Both advantage types can significantly contribute to the reciprocal reinforcing feedback mechanism that makes clusters more attractive as they grow, and lead to further growth (Sheffi, 2012):

- Transportation advantages of logistics clusters comprise a) economies of scale; $b$ ) economies of scope (same fixed capital serves different companies); c) density savings (higher volumes of different flows); d) frequency (higher frequency of services due to diversified and higher volume production of different flows).

- In addition to transportation advantages, logistics clusters offer their members other advantages rooted in their ability to share assets, serve customers better and enable better adjustment to business volume.

Logistics field presents the following agglomeration types: a) logistics service companies (carriers, warehouses and silos, distributors, logistics operators, customs services, IT provision); b) companies with intensive logistics operations (distributors, manufacturers, packing companies, among others), which are often places lacking important transport infrastructures (airports, ports, partly built belonging to the cluster itself); and c) subsidiary service companies (accounting, marketing, law, among others) for companies in items (a) and (b).

\subsection{Ontology}

Ontologies were created many years ago. Ontology using was initially restricted to the Philosophy field. Nowadays, several attempts to define the term, as well as to expand its use to other fields, have taken place and gained interdisciplinary scope.

According to Sartorio (2004), Ontology is a means to present, in a structured way, the concepts of a given knowledge domain and the association between them. Based on Gruber (1993a; 1993b; 1995), in the philosophical sense, building Ontology enables the systematization of existence, i.e., placing everything that exists or, at least, everything that is perceived by man, in the form of a system, as a set of interrelated parts. Unlike what happens in Philosophy, according to which ontologies are representations of a given philosophical line of thinking, ontologies in other fields are collectively built in order to organize knowledge and to promote interaction between systems. The study by Sartorio (2004) has compiled several definitions of Ontology and traced features shared by all of them. These shared features were used in the current research, namely:

- $\quad$ Ontologies are ways to represent knowledge.

- Knowledge represented by Ontologies is shared and consensual.

- Knowledge represented by Ontologies is expressed through concepts and through associations between them.

- $\quad$ Concepts expressed in Ontologies are structured into categories.

- Knowledge represented by a given Ontology belongs to a certain domain.

\subsubsection{Domain Terminologies}

Sartorio (2004) has presented a list of terms widely used in the Ontology domain, whose understanding enables concept assimilation. The following terms were described by Sartorio (2004):

- Knowledge domain: the term is used to define the field associated with the object of construction of an ontology, i.e., with the "clipping" of reality to be represented by the ontology.

- Conceptual relations: refer to associations among the concepts of a given ontology, which are often expressed through verbs.

- Concepts: ideas about things in the world, which derive from observation and experience. Concepts have name and definition.

- Ontological commitment: knowledge-view restriction due to the option made for a particular way to represent it, which sets the way this knowledge should be interpreted by the community sharing it.

- Language: an Ontology can be expressed in natural or logical language. The selected language has impact on Ontology, because it conditions the way of expressing it to the availability of expressive language resources. 
- Axioms: are used in Ontologies to express other relationships between concepts (in addition to the conceptual relationships expressed through verbs) and to restrict their interpretation. They enable representing the knowledge to be improved since, in many cases, concepts and conceptual relationships are not enough.

- Hierarchical categories: concepts can be hierarchically structured from the most general to the most specific level. Hierarchical categories are a way to represent ontologies.

- Vocabulary: is the product of ontologies that comprises all terms accounting for naming and defining concepts and relationships addressed in the Ontology.

\subsection{Interpretive Structural Modeling (ISM)}

Interpretive Structural Modeling (ISM) was first introduced by J. Warfield, in 1974, in order to analyze complex socioeconomic systems. ISM is a computer-assisted learning process that enables individuals or groups of individuals to develop a map of complex relationships among many elements involved in complex situations. Its basic idea lies on using experts' practical experience and knowledge in order to decompose a complicated system into several sub-systems and to build a multilevel structural model. ISM is often used to provide fundamental understanding about complex situations, as well as to put together a course of actions to solve problems.

Thus, Interpretive Structural Modelling (ISM) emerges as an interactive learning process (Attri et. al., 2013) according to which, a set of different directly- and indirectly-related elements are structured into a comprehensive systematic model (Warfield, 1974; Sage, 1977). The so-formed model portrays the structure of a complex issue or problem in a carefully designed pattern comprising graphs, as well as words (Singh et. al., 2003; Raj et. al., 2007; Ravi and Shankar, 2005; Raj and Attri, 2011).

ISM had its inception in Warfield's perception of the need, when attempting to couple science to policy, for "a set of communication tools which have both a scientific and lay character serving as a linkage mechanism between science and the public, and having meaning for all who are involved" and which, in particular, are capable of communicating a holistic sense of the elements and their relations which define system structure (Attri et. al., 2013).

According to Rajesh et. al. (2013), Warfield stipulates a set of requirements for these communication tools which include: i) provision for the inclusion of the scientific elements; ii) means for exhibiting a complex set of relations; iii) means for showing that complex set of relations, which permit continuous observation, questioning and modification of the relations; iv) congruence with the originators' perceptions and analytical processes; v) ease of learning by public (or, by inference, multidisciplinary) audience.

Graphical models or, more specifically, directed graphs (digraphs) appear to satisfy these requirements (Attri et. al., 2013). In such a representation, the elements or components of a system are represented by the "points" of the graph and the existence of a particular relationship between elements is indicated by the presence of a directed line segment. It is this concept of relatedness in the context of a particular relationship which distinguishes a system from a mere aggregation of components (Watson, 1978).

ISM can be used at a high level of abstraction such as needed for long range planning. It can also be used at a more concrete level to process and structure details related to a problem or activity such as process design, career planning, strategic planning, engineering problems, product design, process re-engineering, complex technical problems, financial decision making, human resources, competitive analysis and electronic commerce (Attri et. al., 2013).

\subsubsection{ISM Operation}

The initial step for the application of ISM is to constitute a group of key actors in the resolution of a given problem. Significant elements of the problem in question are extracted from the group of key actors. Then, the significant elements are compared in pairs considering the following question: does the significant element $\mathrm{X}_{1}$ relate to the significant element $\mathrm{X}_{2}$ ?

The series of questions will have "yes" or "no" answers, which will constitute the so-called ISM Description Matrix (D). The lines and columns of this matrix represent the significant elements of the problem and the response between them will be expressed by the binary values 1 (yes) and 0 (no) (Figure 2). 


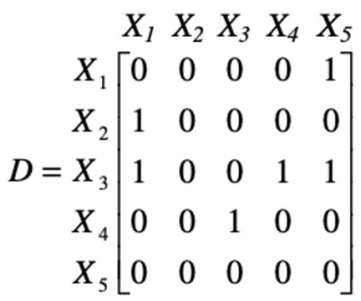

Figure 2. Description matrix (Source: Sartório, 2004)

Warfied (1974) realized that in order to obtain a complete picture of the problem, it would be necessary to propagate the influence of the elements in each line of the matrix in order to highlight the paths of each element in accordance with the problem, thus, Warfied created the Access Matrix (M) using the Successive Boolean Potentials represented by the equation (1) and the Figure 3.

$$
M=(D+I)^{n}=(D+I)^{n+1}
$$

Thus:

M: access matrix;

D: description matrix;

I: identity matrix;

n: number of interactions required.

$$
M=\left(\left[\begin{array}{lllll}
1 & 0 & 0 & 0 & 1 \\
1 & 1 & 0 & 0 & 0 \\
1 & 0 & 1 & 1 & 1 \\
0 & 0 & 1 & 1 & 0 \\
0 & 0 & 0 & 0 & 1
\end{array}\right] *\left[\begin{array}{lllll}
1 & 0 & 0 & 0 & 1 \\
1 & 1 & 0 & 0 & 0 \\
1 & 0 & 1 & 1 & 1 \\
0 & 0 & 1 & 1 & 0 \\
0 & 0 & 0 & 0 & 1
\end{array}\right]\right)^{n}=\left(\left[\begin{array}{lllll}
1 & 0 & 0 & 0 & 1 \\
1 & 1 & 0 & 0 & 0 \\
1 & 0 & 1 & 1 & 1 \\
0 & 0 & 1 & 1 & 0 \\
0 & 0 & 0 & 0 & 1
\end{array}\right] *\left[\begin{array}{lllll}
1 & 0 & 0 & 0 & 1 \\
1 & 1 & 0 & 0 & 0 \\
1 & 0 & 1 & 1 & 1 \\
0 & 0 & 1 & 1 & 0 \\
0 & 0 & 0 & 0 & 1
\end{array}\right]\right)^{n+1}
$$

Figure 3. Access matrix (Source: Sartório, 2004)

When the access matrix stabilizes, i.e., the next points in the matrix do not generate new values, the final result of the interactions is obtained.

\section{Methodology Proposed}

The herein proposed methodology was used to investigate the developmental stages of an important logistics cluster in Europe - i.e. the Logistics in Wallonia, Belgium - in order to identify the variables necessary to develop clusters, as well as to better understand the association among all the identified variables. Thus, the Interpretive Structural Modeling (ISM) developed by J. Warfield (1974) was used to create an ontology comprising several variables capable of affecting the development of logistic clusters, as well as to assess the association among these variables and to monitor the impact of the main aspects in order to indicate the main associations to be taken into consideration.

The developed methodology was used to collect data through interviews conducted with key actors of the logistics cluster development process (managers, researchers, professors), and it provided qualitative results that were analyzed later (subjective judgments and interpretations). Thus, the methodology presented in this section comprised seven (7) steps, which can be used to help technicians at the time to implement logistics clusters in a given region, namely:

- Step 1: Defining the Aim of the Study

- Step 2: Defining and Describing the Study Area

- Step 3: Defining the Object of Study

- Step 4: Limiting the Knowledge Domain

- Step 5: Identifying the Variables Necessary to Develop Logistics Cluster 
- Action 4.1: Defining the trigger question

- Action 4.2: Identifying concepts (variables)

- Step 6: Building an Ontology to Develop the Logistics Cluster

- Action 6.1: Explaining the concepts to key actors

- Action 6.2: Using ISM to create the ontology to develop logistics cluster

- Step 7: Presenting and Describing the Basic Ontology to Develop Logistics Cluster

\section{Identifying Variables and Creating the Ontology Necessary to Develop Logistics Cluster}

\subsection{Step 1: Defining the Aim of the Study}

The main aim of the current study was to create a methodology in order to identify variables capable of affecting the implementation of a logistics cluster in a given region, by taking into consideration the experiences, knowhow and visions of the key actors who worked in the cluster-development policy process, as well as the role played by logistic clusters in regional planning and economic development. Moreover, the aforementioned methodology was applied to the case of Logistics in Wallonia (Belgium) in order to validate it.

\subsection{Step 2: Defining and Describing the Study Area}

The Walloon Region in Belgium, mainly the Province of Liège, was the herein selected study area, since it hosts the main clusters in the country. Thus, political, administrative, transportation, logistics and economic aspects of the study site were herein described.

\subsubsection{Political and Administrative Aspects}

First, it is necessary understanding how Belgium is administratively constituted, based on political and economic decision-making aspects. In accordance with Belgium (2019) "the redistribution of power occurred along two lines. The first line relates to language and, in a broader sense, to everything related to culture. The result was several communities. The concept of 'community' refers to persons that make up a community and the bond that unifies them, namely their language and culture. The second line of state reform was historically inspired by economic interests."

The regions, which aspired to more economic autonomy, conveyed these interests. The establishment of the three regions was the result: the Flemish Region, the Brussels Capital Region and the Walloon Region. The Flemish and Walloon regions comprise 10 provinces and 589 municipal councils. The Federal State, nevertheless, retains important powers, for example in the area of foreign affairs, national defense, justice, finance, social security, important parts of national health and domestic affairs... However, the communities and the regions also have the power to establish and maintain foreign relations (Belgium, 2019).

The Province of Liège is formed by four administrative arrondissements (districts), such as the Arrondissement of Liège, which comprises 24 municipalities, namely: Ans, Awans, Aywaille, Beyne-Heusay, Bassenge, Blegny, Chaudfontaine, Comblain-au-Pont, Dalhem, Esneux, Flémalle, Fléron, Grâce-Hollogne, Herstal, Juprelle, Liège, Neupré, Oupeye, Saint-Nicolas, Seraing, Soumagne, Sprimont, Trooz and Visé. Arrondissements are subdivisions of Belgium provinces. The country has administrative, judicial and electoral arrondissements that may, or may not, relate to identical geographical areas.

The current study was developed in Walloon Region, more specifically in Liège, which is a French-speaking city located in Eastern Belgium (Figure 4). It is the capital of the province of Liège and it is known as the economic capital of Walloon Region. From 972 to 1795 , it was the capital of the Principality of Liège. From the $7^{\text {th }}$ to the $16^{\text {th }}$ century, it was the seat of the vast Bishopric of Liège, heir to the Civitas Tungrorum. 


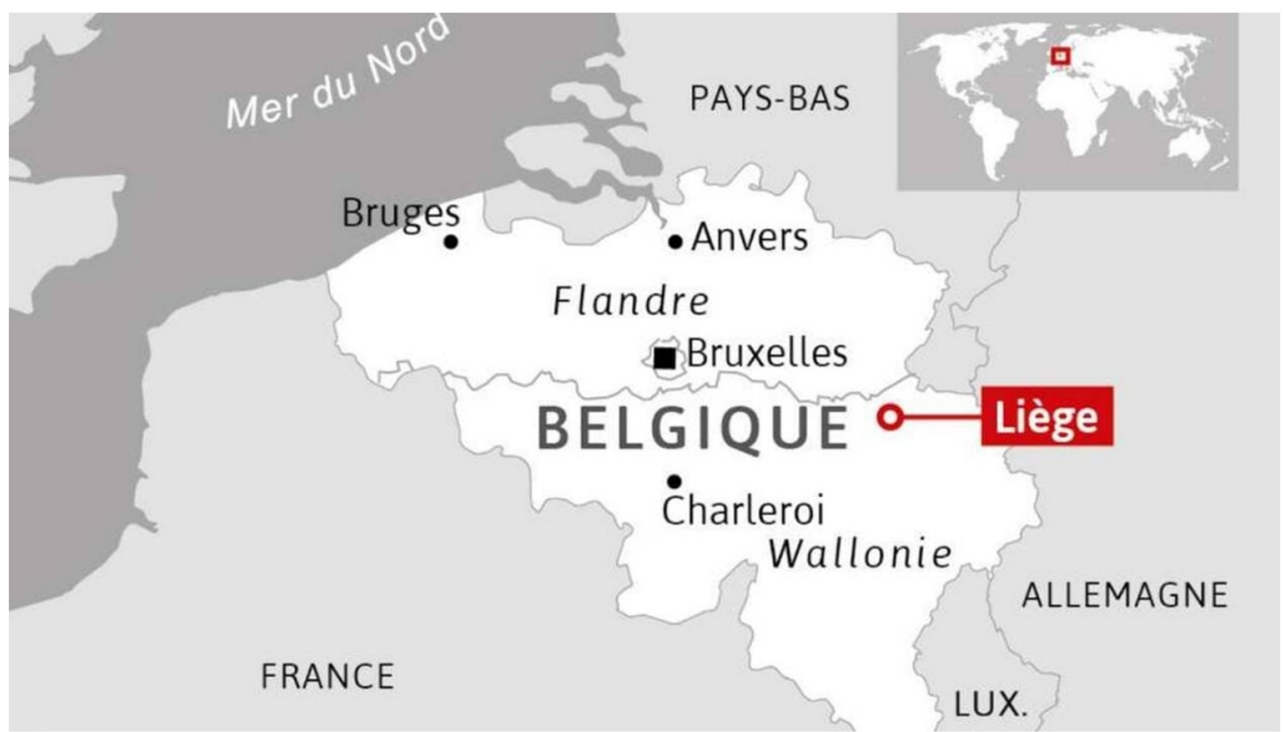

Figure 4. Liège municipality located at Walloon Region in Belgium (Source: Ouest France, 2019)

According to reports by STATBEL (2019) from January $1^{\text {st }}, 2019$, the Province of Liège has 1,106,992 inhabitants, the Walloon Region has 3,633,795 inhabitants and Belgium has 11,431,406 inhabitants. In other words, the population living in Province of Liège corresponds to approximately $30.5 \%$ of the population in Walloon Region and to approximately $9.70 \%$ of the Belgium population. In 2018, Liège had 197,355 inhabitants. If one takes into consideration the number of inhabitants living in Liège, it is possible saying that the municipality is the first Walloon agglomeration, the third Belgium agglomeration after Brussels and Antwerp, and the fourth municipality after Antwerp, Ghent and Charleroi. Province of Liège covers the total area of $3,857 \mathrm{~km}^{2}$ and presents population density of 288 inhabitants $/ \mathrm{km}^{2}$. Its DHI in 2017 reached 0.884 (Province de Liège, 2019).

\subsubsection{Transportation and Logistics Aspects}

Based on the accessibility approach, Liège strongly relies on transportation and multimodality, which make it very well connected to Europe and to the rest of the world. Figure 5 presents the map of Walloon Regions and the main logistics facilities surrounding Liège.

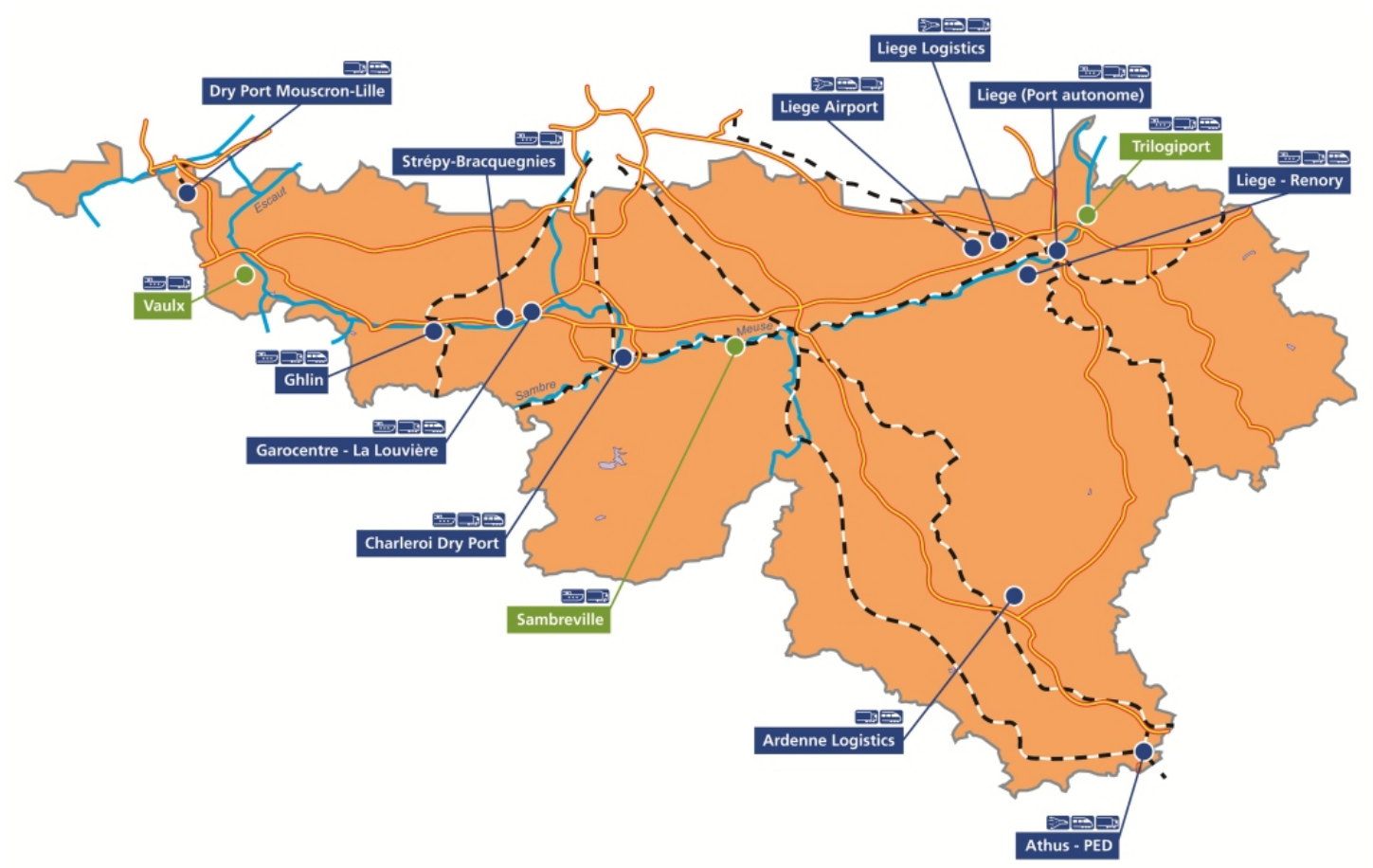

Figure 5. Walloon Region and the main logistics facilities surrounding the Province of Liège (Source: Logistics in Wallonia, 2020) 
Thus, Liège is an important economic center located at the heart of the European transportation network. It has logistical advantages such as the Autonomous Port of Liège, which is the second European river port (Figure 6a); the current development of the Trilogiport (Figure 6b), which a multimodal platform for containers along the Albert Canal; the very recent Liège-Guillemins station (Figure 6c); and the new TGV lines traveling from Brussels to Liège and from Liège to the German border. The road transportation system comprises a very large 7-branch motorway network (E40 to Brussels and Aachen, E42 to Namur and Verviers, E25 to Maastricht and Luxembourg, E313 to Antwerp). Liège Airport, which is the eighth European airport for the air transportation of goods, lies only $12 \mathrm{~km}$ away from downtown Liège (Figure 6d). Liège is also easily accessed via Brussels South Charleroi Airport and Brussels Airport, which are less than 100km away from the city, or via Maastricht Airport, which is even closer - $30 \mathrm{~km}$ away from it.

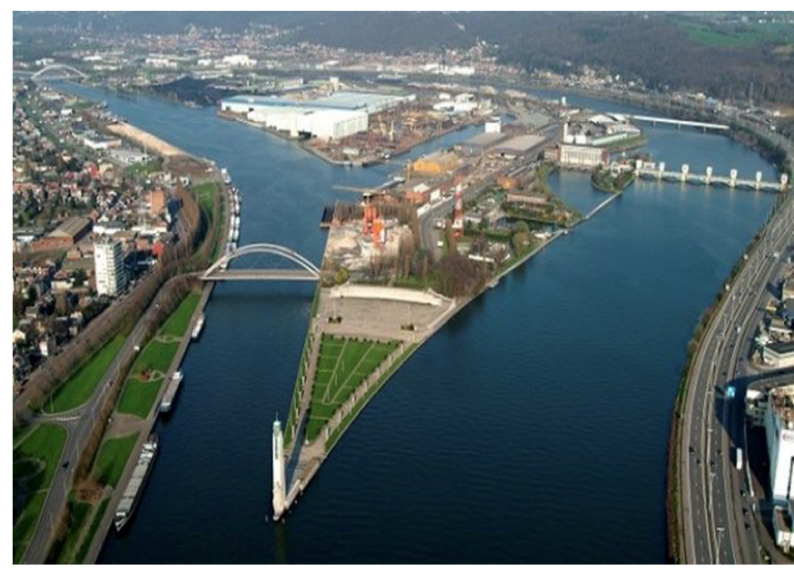

(a)

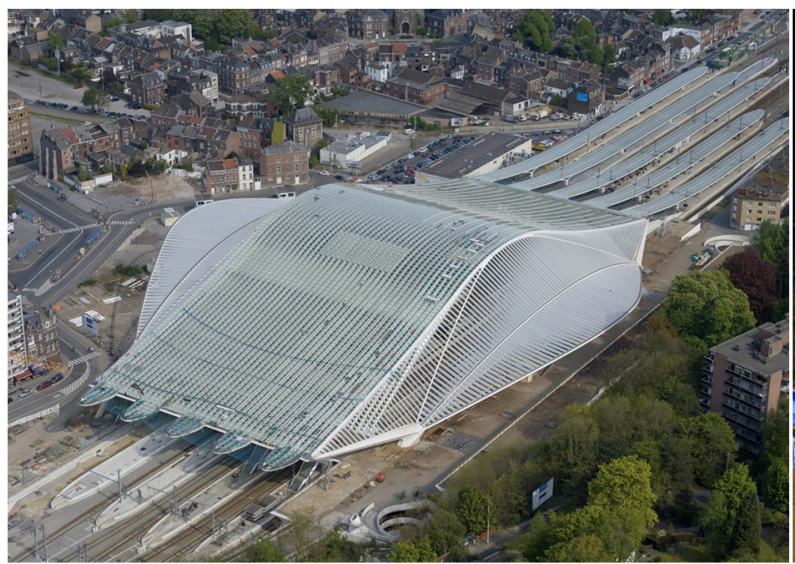

(c)

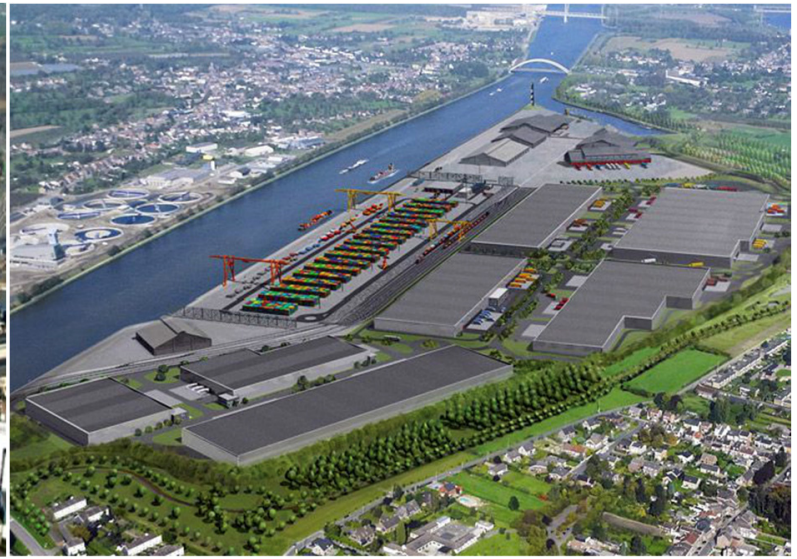

(b)

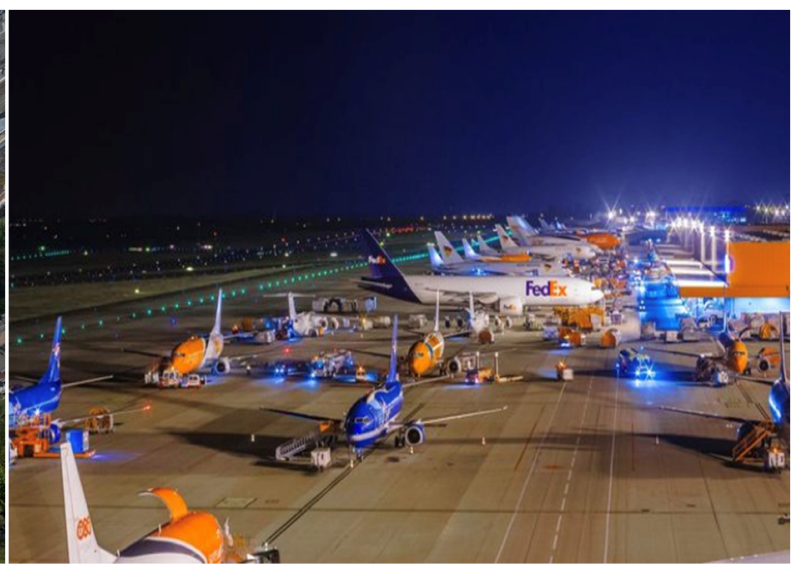

(d)

Figure 6. Main Transportation Facilities at Province of Liège: (a) Port of Liège; (b) Trilogiport; (c) LiègeGuillemins Station (Source: Infosteel, 2019) and (d) Liège Airport

\subsubsection{Economic Aspects of the Province of Liège and Walloon Region}

Liège has long been a large industrial city (in the mid- $19^{\text {th }}$ century, the Walloon industrial furrow was the first industrial region in the continent). However, from the 1960s onwards, it experienced a long decline, since its factories became obsolete (La Wallonie Fédérées, 2010). Reid \& Musyck (2010) have described the industrial situation of the Walloon Region in the 1960s:

"In the century and a half up to the 1960s, the Walloon economy was one of the most prosperous in Europe: its growth during this period was linked to industry rather than agriculture; to large firms (particularly in basic industries) rather than to small and medium-sized enterprises (SMEs). At the time of the first industrial revolution, Wallonia was equipped with numerous comparative advantages in the leading sectors of the epoch: 
coal mining, steel making and their spin-off activities. Natural resources, a highly skilled workforce and the dynamism of its engineers were the foundations on which Wallonia built its prosperity."

Reid \& Musyck (2010) complete the description of the industrial situation and economic decline of the Walloon Region as follows:

"None the less, this largely positive profile contained the seeds of a decline, which began in the inter-war period. In the decades which followed, a series of factors arose which disturbed the previously 'virtuous circle':

- the natural resources were progressively exhausted, extraction of ores became more and more expensive with the first pits being closed in 1958;

- more modern raw materials were increasingly imported by sea through the port of Antwerp giving an advantage to Flanders as a location for industrial activities;

- competition for the provision of basic industrial products became increasingly harsh over the years with direct competitors from Western and Eastern Europe, benefiting from lower costs (particularly labour-related);

- and, finally, a majority of industrial production remained focused on basic and intermediate goods with a generalized failure to diversify towards higher value-added finished products."

The economic decline has forced federal and regional governments to develop regional economic policies, as well as to create a legislation to boost the economy based on the identification of its key sectors. This process has led to research development and, consequently, to economic growth, increase in the number of job positions and welfare state improvement. In terms of competencies returned to the sub-federal level, a series of constitutional laws has progressively given exclusive competence to regions in the following policy fields since 1980 (Reid \& Musyck, 2010), namely: economic policy; regional aspects of credit policy; external trade (grants the right to coordination at federal level); international relations, including the right to conclude treaties; town and country planning; research and scientific policy; transport and energy infrastructures; rural, agricultural and environmental policy.

A series of important political and economic events has emerged from regional economic policies created by the government; these policies have led to the creation of competitive poles and, finally, to competitive clusters in Walloon Region. These events can be chronologically identified as follows (Lepage, 2007):

- The first initiative was that of a neutral organization, the University of Liège via its Interfaculty Transportation Group chaired by Professor Jean MARCHAL who persuaded the university chancellor, Professor Willy LEGROS to back it. During the first two years the development of the project was entrusted to the University-Business Interface which selected the first social actors, influential in their sectors, to participate, among them Jean-Marie Becker (private sector, road transportation) and Francis Hambye (General Manager at the Ministry of Equipment and Transportation). That was important in ensuring that from the start development would be harmonious with a gradual building of trust among cluster members and to foster that end a communication/information policy was implemented.

- After the start-up period a management board was created with members drawn from both public and private sectors.

- In 1988, the airport system in Belgium has changed into regional management; such an event has triggered the growth of regional airports:

- As a result, Charleroi Airport was focused on passengers' transportation, whereas Liège Airport $(07 / 24 / 1988)$ was focused on freight transportation.

- In 1998, TNT has moved to Liège Airport and started using it to transport its products.

- In 1999, the "Pole Transport" in Walloon was launched by Jean-Marie Becker, Willy Legros (rector of ULg) and Francis Hambye (General Manager of the Ministry of Equipment and Transport). The "Pole Transport" was created to encourage collaboration among different transport modes, as well as to promote the development of new logistics activities.

- Formalization of competitive clusters: the $1^{\text {st }}$ cluster policy was enacted in 2001, when strategic actions focused on developing clusters in the Walloon Region were taken. 
- In 2004, the "Pole Transport" requested its acknowledgement as official cluster and expanded its activities in the entire Walloon Region.

- In 2005, the Marshall Plan (Dujardin et. al., 2019) was implemented in Belgium in order to encourage the country's economy to focus on the following sectors: life-science, agri-food; clean techs and mechanics; aerospace; transportation and logistics.

- In 2007, the "Pole Transport" has changed into a competitive cluster approach and became known as Logistics in Wallonia. Logistics in Wallonia started receiving resources from the Marshall Plan in order to finance transportation and logistics projects. Biowin (biopharma); Greenwin (chemistry); Mecatech (mechanical engineering); Skywin (aeronautics and space) and Wagralim (transport logistics) were the other clusters implemented in Walloon Region. Figure 7 shows the location of Walloon and Brussels' members of six competitive clusters in 2018.

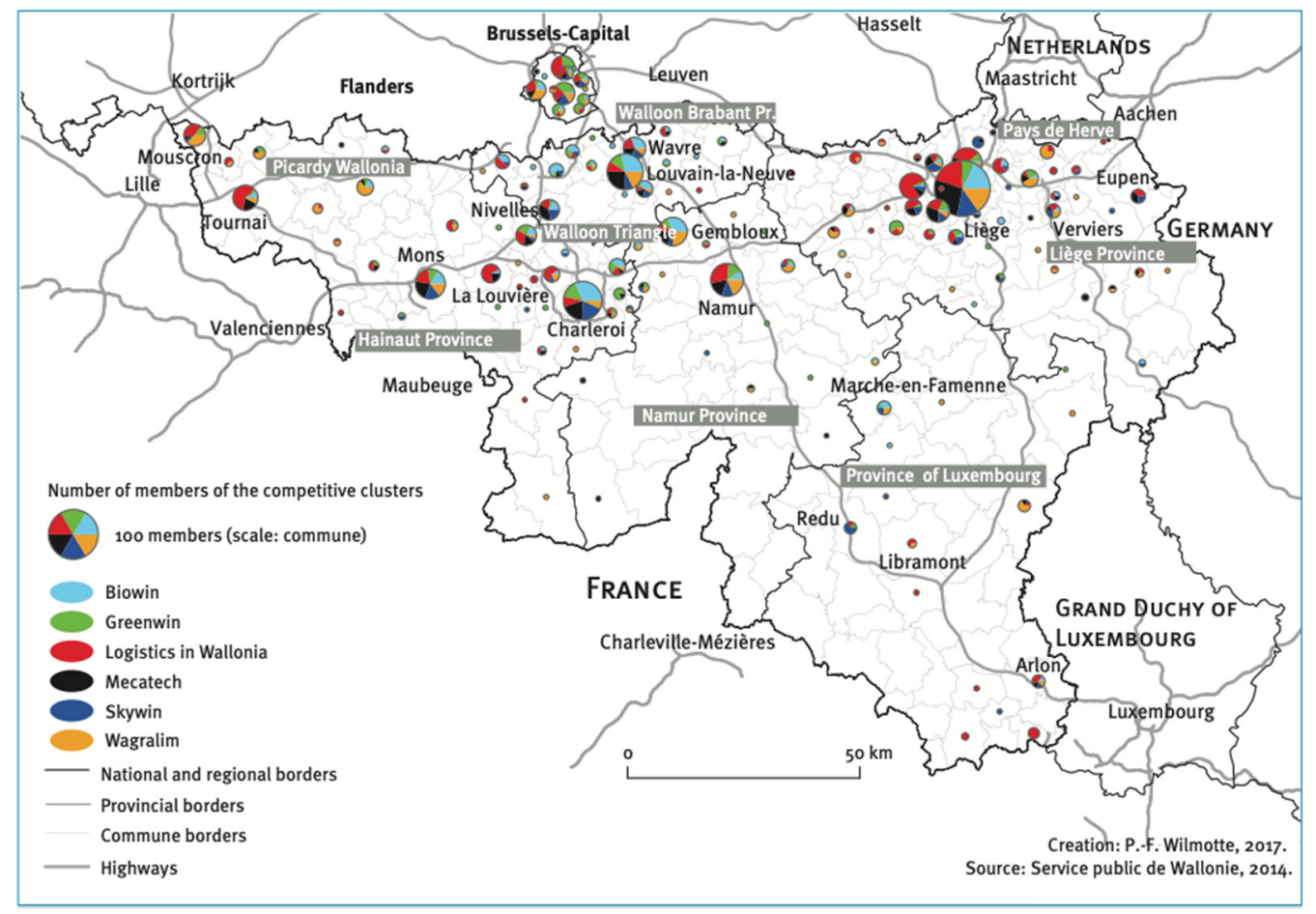

Figure 7. Location of Walloon and Brussels' Members of Six Competitive Clusters in 2018 (Source: Wilmotte and Halleux, 2018)

Regional economic policies developed by the government to encourage the regional economy were implemented based on two main measures: investment incentives; R\&D assistance, including technology transferring and innovation initiatives.

\subsection{Step 3: Defining the Object of Study}

The cluster known as Logistics in Wallonia, whose head office is based in Liège Airport, is the object of the current study. It was launched in 2007 as the competitiveness cluster focused on the transportation, logistics and mobility sector in Walloon Region. Logistics in Wallonia is at the heart of a network comprising 365 members; it is focused on the following players (Logistics in Wallonia, 2020): carrier and logistics service providers; clients or shippers from different industrial sectors, including biotechnologies, the food industry or the distribution sector; infrastructure managers; suppliers, component manufacturers and service providers; players in the training sector; innovators (businesses, universities and research centers); federation and association sectors.

Logistics in Wallonia is financed by the regional government, membership fees and private revenues, which enable promoting actions in five (5) strategic axes, as follows:

- Innovation: encouraging the competitiveness and contributing to the economic, technological and scientific development of Walloon region through R\&D projects. 
- Business Community: developing and strengthening partnerships between members; encouraging integration among the economic, technological and scientific fields in Walloon and beyond.

- Human Capital Management and Development: close collaboration to training organizations in order to adapt training programs, job-offer analysis and innovative training programs.

- International: encouraging competitiveness by pooling Walloon skills and resources with international partners; creating conducive conditions to internationalize their activities.

- Marketing: improving the image and awareness of Walloon based on actions focused on circulating concrete information about its assets in terms of logistics and innovation in mobility.

\subsection{Step 4: Limiting the Knowledge Domain}

Limiting the knowledge domain is a fundamental part of the research whose focus is centered. According to Sartorio (2004), based on a certain knowledge domain, it is possible identifying and analyzing its components, investigating the association among them and building a certain ontology. Thus, the knowledge domain of the current study lies on logistic analysis and cluster development.

\subsection{Step 5: Identifying the Variables Necessary to Develop Logistic Clusters}

Once the knowledge domain was defined, it was possible emphasizing the aspects and features to be analyzed in the study, mainly the ones associated with logistics clusters. Such aspects may be interpreted as the variables necessary to develop logistics clusters. Thus, two main actions were taken into account to enable identifying these variables and creating the ontology necessary to develop the logistics cluster, namely: i) defining the trigger question and ii) identifying concepts.

Action 5.1: Defining the Trigger Question

The first action to be taken into consideration lies on defining the trigger question used to guide the brainstorming technique application to key actors involved in the cluster development process, in order to identify the variables necessary to develop the logistics cluster. The trigger question definition process has followed the aim of the current study. It was possible identifying what should be known to develop the logistics cluster based on the key actors' know-how and experience in the knowledge domain. Thus, the herein defined trigger question was "what is necessary to develop a logistic cluster in order to contribute to the economic growth of a given region?"

Action 5.2: Identifying Concepts (Variables)

The trigger question was applied to key actors, based on the brainstorming technique, in order to identify the concepts necessary to develop logistics cluster. First, it was necessary identifying these actors. Five key actors were identified in the current case study, based on the experience and role played by them in cluster development and management. The profiles of the key actors comprised:

- General manager of the cluster Logistics in Wallonia.

- Senior researcher-professor who worked in the "Pole Transport" deployment process.

- Manager who worked in the innovation sector of the cluster Logistics in Wallonia.

- Technician who worked with technology transferring at the Business-University Interface, which is the knowledge transferring office at University of Liège.

- Technician who worked with project management at the Business-University Interface, which is the knowledge transferring office at University of Liège.

The brainstorming technique applied to the key actors enabled identifying forty-five (45) variables, which were considered important for the logistics cluster development process. Table 1 shows the list of all variables identified through interviews conducted with the aforementioned key actors.

\subsection{Step 6: Building the Ontology to Develop Logistics Cluster}

This step accounts for building the ontology (framework) necessary to help better understanding the association among variables capable of affecting the development of logistic clusters. The actions taken at this step were substantiated by ontology concepts and terminologies used to create a framework of associations among forty-five (45) variables, based on the Interpretative Structural Modeling (ISM). This step was based on two actions: i) explaining the concepts to key actors, and ii) using the Interpretative Structural Modeling (ISM) to create the ontology. 
Table 1 . Variables identified by key actors as necessary to develop logistics clusters

\begin{tabular}{|c|c|c|c|}
\hline $\mathrm{N}^{\mathrm{o}}$ & Variable & $\mathrm{N}^{\mathrm{o}}$ & Variable \\
\hline 1 & Effective Government (financial) support & 24 & Development of masterplan for the cluster project \\
\hline 2 & Efficient infrastructure of transport & 25 & Consolidated productive agglomerations \\
\hline 3 & $\begin{array}{l}\text { Existing of qualify labour in key sectors of the local } \\
\text { economy }\end{array}$ & 26 & Local competition among companies \\
\hline 3 & $\begin{array}{l}\text { Existing of qualify labour in key sectors of the local } \\
\text { economy }\end{array}$ & 26 & Local competition among companies \\
\hline 4 & Strong local industries and companies & 27 & $\begin{array}{l}\text { Regional, nacional and international commercial } \\
\text { cooperation }\end{array}$ \\
\hline 5 & $\begin{array}{l}\text { Identifying services to be offer: development and } \\
\text { innovation, networking, up-to date information }\end{array}$ & 28 & $\begin{array}{l}\text { Effective regional policy of innovation and } \\
\text { technology }\end{array}$ \\
\hline 6 & Identifying demand from the industries and companies & 29 & Well defined cluster's boundaries \\
\hline 7 & Support from research \& development & 30 & $\begin{array}{l}\text { Effective participation of the key actors on the project } \\
\text { development }\end{array}$ \\
\hline 8 & $\begin{array}{l}\text { Interest of the companies on the development of the } \\
\text { cluster }\end{array}$ & 31 & $\begin{array}{l}\text { Permanent agenda of meeting with key actors } \\
\text { involved in the project }\end{array}$ \\
\hline 9 & Identifying the key actors in the region & 32 & $\begin{array}{l}\text { Identifying competitive sectors (competitive poles) in } \\
\text { the region }\end{array}$ \\
\hline 10 & Identifying the value chains in the region & 33 & Building trust relationship \\
\hline 11 & Economic support from finance market & 34 & $\begin{array}{l}\text { Understanding the ecosystem of the cooperation } \\
\text { (government, companies and universities) }\end{array}$ \\
\hline 12 & Labour market for development support of the cluster & 35 & $\begin{array}{l}\text { Selection of cluster priority actions: innovation, } \\
\text { communication, human resources, etc. }\end{array}$ \\
\hline 13 & Local supplies consolidated & 36 & $\begin{array}{l}\text { Understanding of the importance of companies } \\
\text { working in partnership }\end{array}$ \\
\hline 14 & Effective local associations & 37 & Definition of strategy axes of the cluster \\
\hline 15 & $\begin{array}{l}\text { Long-term alliances between productive sector of the } \\
\text { region and government }\end{array}$ & 38 & $\begin{array}{l}\text { Evaluation of proposed actions for cluster } \\
\text { development }\end{array}$ \\
\hline 16 & Local buzz & 39 & $\begin{array}{l}\text { Mapping of stakeholder interests involved on the } \\
\text { project }\end{array}$ \\
\hline 17 & Strong local buyers & 40 & $\begin{array}{l}\text { Effective participation of the research centres } \\
\text { (universities) on the project development }\end{array}$ \\
\hline 18 & Regional, national and international strategic partners & 41 & $\begin{array}{l}\text { Real cooperation with different actors envolved to the } \\
\text { cluster }\end{array}$ \\
\hline 19 & Clear future vision of cluster development project & 42 & Cluster policy development \\
\hline 20 & High level of trust between companies and public sector & 43 & Creating university-business interface \\
\hline 21 & Resources and legitimacy of the local government & 44 & $\begin{array}{l}\text { Creating effective management, monitoring and } \\
\text { evaluation structures }\end{array}$ \\
\hline 22 & Facilitator with high legitimacy and strong networks & 45 & Efficient complementary management team \\
\hline 23 & $\begin{array}{l}\text { Good co-ordination among different parts of the public } \\
\text { and private sectors }\end{array}$ & & \\
\hline
\end{tabular}


Action 6.1: Explaining the Concepts (Variables) to Key Actors

The first action taken at this step lied on explaining the concepts (variables) to key actors. It was necessary describing all features of each concept to the main person accounting for managing the cluster Logistics in Wallonia. It is important describing these variables to help better understanding the concepts in order to properly analyze the association among variables. Thus, variables were described based on concepts available in the technical literature.

Action 6.2: Using the Interpretative Structural Modeling (ISM) to Create the Ontology Necessary to Develop the Logistics Cluster

As previously described, ISM is an interactive learning process comprising a set of different elements directly and indirectly related to each other and structured in a comprehensive systematic model (Warfield, 1974; Sage 1977). The so-formed model portrays the structure of a complex issue in a carefully designed pattern implying graphs and text. Thus, ISM was used to create an ontology (structure), based on the following sequence of actions:

1) Opening the ISM software for application.

2) Creating a file name to be applied.

3) Inserting data about the key actor in the file.

4) Loading the file with all variables identified in Action 5.2.

5) Creating the matrix of variables' association.

6) Applying the association matrix to key actors. Matrix application takes into consideration the following question to be asked to key actors: does variable "a" influence variable " $\mathrm{b}$ " in the cluster policy context? If the actors answered "yes", the cell should be filled with value 1. If they answered "no", the cell should be filled with value 0 .

7) Creating the basic ontology used to develop the logistics cluster.

\subsection{Step 7: Presenting and Describing the Basic Ontology Used to Develop Logistics Cluster}

Finally, the present step presents the basic ontology used to develop the logistic cluster. Figure 8 presents the ontology comprising concepts (variables), conceptual relations (arrows), axioms (labels), hierarchical categories (levels), and main concepts (bottlenecks).

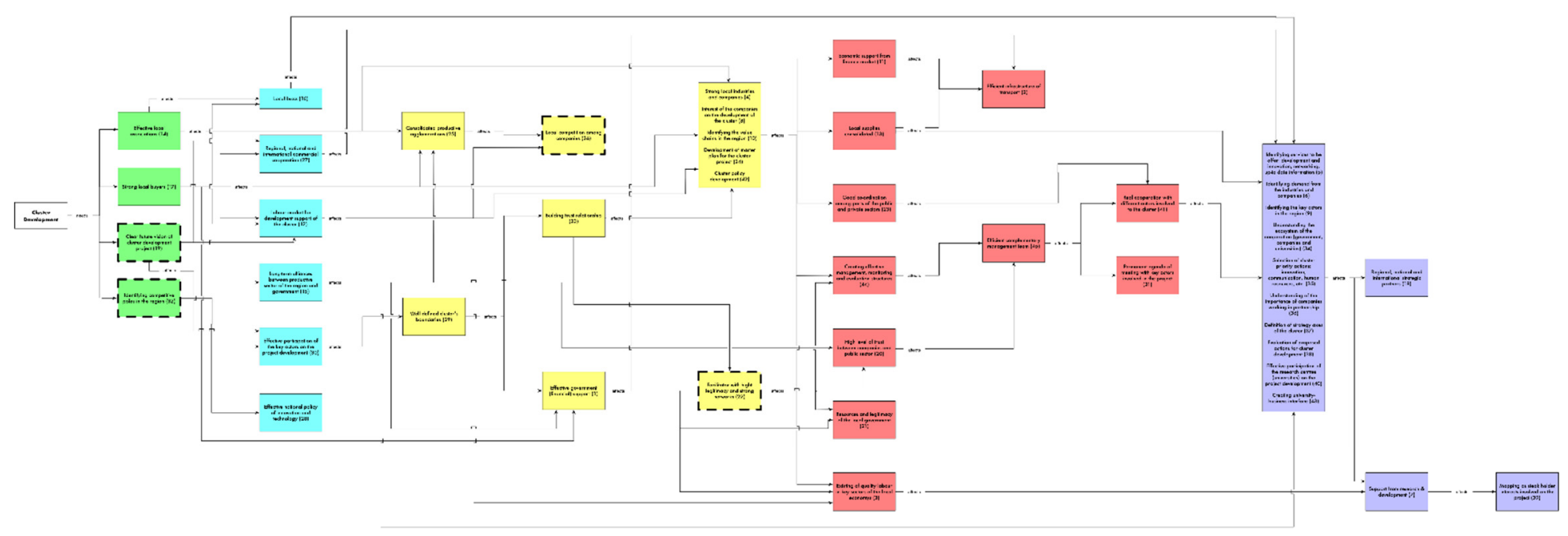

Figure 8. Basic ontology for logistics cluster development (Source: own author) 
The ontology built to develop the logistics cluster comprised 45 variables, which were interrelated in a way that can be understood as a logic framework encompassing five (5) different levels: $1^{\text {st }}$ level - precondition; $2^{\text {nd }}$ level surrounding condition; $3^{\text {rd }}$ level - foundation condition; $4^{\text {th }}$ level - operation $\&$ management conditions; $5^{\text {th }}$ level management and strategy conditions. Such levels (conditions) describe associations within the set of variables in a sequence that should be followed to ensure the control of aspects necessary for the logistics cluster development process.

Based on the ontology presented in Figure 8, it is possible simultaneously meeting two or more variables at a given time, without losing control of actions capable of affecting the logistics cluster development process. Moreover, based on key actors' viewpoint, it was possible identifying four restrictions in the ontology system - also known as "bottlenecks" -; they can affect logistics cluster development. In other words, these bottlenecks are important aspects in the whole framework; thus, it is necessary focusing on controlling them in order to keep ontology's effectiveness. These bottlenecks are described as follows:

- Clear future vision about the cluster development project (19).

- Identifying competitive poles in the region (32).

- Local competition among companies (26).

- Facilitator with high legitimacy and strong networks (22).

Based on Figure 8, it is possible understanding the reason why these four aspects were previously identified as bottlenecks, i.e., they were closely linked to several ontology variables, which allowed supposing that the poor control of actions linked to such variables can affect the performance of the logistics cluster development system. Moreover, the experience of key actors in creating and developing the cluster Logistics in Wallonia, certainly enables stating that these variables must be properly managed and controlled in order to get to the expected results at each ontology level.

\section{Conclusions}

The regional development policy is a process comprising several activities, and its success depends on several aspects, such as the plan to be elaborated, key actors' identification, the method to be created, tools to be used, among others. Thus, clusters can be considered an important tool to promote regional economic development. However, according to Porter (1998), cluster using as regional economic development instrument can only be achieved when there is integration between government and private sector's interests, and when research institutions are seen as elements capable of designing innovation and technology in pursuit of effective results.

According to Oxford Research (2012), cluster development planning encompasses some steps; diagnosis is one of the most important step of such a planning. However, diagnosis can only be efficient when the variables necessary to promote cluster development are identified. The aim of the current research was to create a methodology capable of identifying the variables necessary to develop logistic clusters.

Thus, the current study has contributed to the development of a methodological procedure capable of identifying the variables necessary to develop logistics clusters. Consequently, it can be used to plan and evaluate these clusters, since it integrates technical requirements of cluster analysis to the perspectives of key actors accounting for cluster development processes. Such an integration was performed by using ontology-related concepts and the Interpretative Structuring Modeling (ISM) tool.

It is essential emphasizing that the herein developed method can be easily applied and that the identified variables can be used in other cases presenting context similar to that of Walloon Region. Nevertheless, it is always necessary taking into consideration specificities of the study site at the time to apply any consolidated method or to develop a new method to investigate any phenomenon, including the one investigated in the current research, namely: the development and analysis of clusters.

A set of other variables relevant to the cluster development process may arise in developing countries. Therefore, they should be taken into consideration in cluster creation and analysis processes. Such aspects may be easily adapted and taken into consideration at the time to apply the method developed in the present research.

Finally, several variables were identified and connected to each other based on the association among them and on their hierarchical importance in the cluster development context, namely: i) pre-condition; ii) surrounding condition; iii) foundation condition; iv) operation \& management conditions; v) management \& strategy conditions. The following topics should be developed in future research:

- Applying the Theory of Constraints (TOC) to identify priorities and actions to be taken to help controlling 
bottlenecks.

- Sensibility analysis of variables necessary to logistics cluster development processes.

- Developing a methodology capable of structuring logistics clusters based on the regional economic growth approach.

- Econometric analysis of clusters 'influence on company members 'performance.

\section{Acknowledgments}

A special thanks to the Wallonie - Bruxelles International.be (WBI) for its financial support of the study. Thanks to Logistics in Wallonia for providing the data and information necessary for the development of this study. Special thanks to Mr. Bernard Piettre for his collaboration and time for the development of the study. Thanks to the Urban and Environmental Engineering Department, Center for Transport, Mobility \& Logistics of the Liège University for hosting, technical support, the facilities used and the necessary infrastructure for the development of this study. Special thanks to fellow professors Jean Marchal and Mario Cools of the Université de Liège for the support, encouragement, guidance and assistance in conducting the study. Without their participation, it would not have been possible to develop this paper. Thanks to the technicians of the Interface Entreprises - Universite de Liège, and especially to the Mr. Eric Feller for encouragement in this research.

\section{References}

Attri, R., Dev, N., \& Sharma, V. (2013). Interpretive Structural Modeling (ISM) approach: An Overview. Research Journal of Management Sciences, 2(2), 3-8.

Becattini, G. (1990). The marshallian industrial district as a socio-economic notion. In Pike, F., Becattini, G., \& Sengenberger, W. (Eds.), Industrial districts and interfirm cooperation in Italy. International Institute for Labour Studies, ILO, Geneva.

Belgium. Retrieved December, 2019, from https://www.belgium.be/en/about_belgium/government/federale_staat

Davis, C. H., Arthurs, D., Cassidy, E., \& Wolfe, D. (2006). What Indicators for Science, Technology and Innovation Policies in the 21st Century? Ottawa.

De Souza, N. D. J. (1981). Economia Regional: Conceito E Fundamentos Teóricos. Perspectiva Econômica, Universidade do Vale Rio dos Sinos, v. 11, n. ano XVI.

Dujardin, C., Louis, V., \& Scourneau, V. (2018). La politique des pôles de compétitivité dans le cadre de la Stratégie de spécialisation intelligente - Analyse évaluative. Revue d’Économie Régionale \& Urbaine, pages 417 à 462. https://doi.org/10.3917/reru.182.0417

Gruber, T. (1993a). What is ontology? Stanford University. Retrieved January, 2020 from http://wwwksl.stanford.edu/kst/what-is-an-ontology.html

Gruber, T. (1993b). A Translation Approach to Portable Ontology Specifications. Knowledge Acquisition, 5(2), 199-220. https://doi.org/10.1006/knac.1993.1008

Gruber, T. (1995). Towards Principles for the Design of Ontologies Used for Knowledge Sharing. International Journal of Human-Computer Studies, 43(5-6), 907-928. https://doi.org/10.1006/ijhc.1995.1081

Infosteel. (n.d.). Gare de Liège-Guillemins. Retrieved December, 2019 from https://www.infosteel.be/fr/projets/96-non-residentiels/621-gare-de-liege-guillemins.html

Keller, P. F. (2008). Clusters, Distritos Industriais E Cooperação Interfirmas: Uma Revisão Da Literatura - Revista Economia \& Gestão da PUC Minas, V. 8, N. 16.

La Wallonie, entité fédérée. Retrieved January, 2020 from http://mrw.wallonie.be/sg/dsg/dircom/walcartes/pages/txt540.htm

Lepage, V. (2007). Le clustering en Wallonie. Territoire(s) wallon(s). Hors série.

Lipsey, \& Chystal, A. (2011). Economics (12th ed.). Oxford University Press.

Logistics in Wallonia. Retrieved January, 2020 from https://www.logisticsinwallonia.be

OECD. (1999). Boosting Innovation: the Cluster Approach. Paris, Organization for Economic Cooperation and Development. https://doi.org/10.1787/9789264174399-en

OECD. (2002). Dynamising National Systems of Innovation. Paris, Organization for Economic Co-operation and Development. https://doi.org/10.1787/9789264194465-en 
Ouest France. (n.d.). Un policier grièvement blessé à Liège, son agresseur abattu. Retrieved December, 2019 from https://www.ouest-france.fr/europe/belgique/belgique-un-policier-grievement-blesse-liege-son-agresseurabattu-6511657

Oxford Research. (2012). Cluster Development Manual: 10 Steps to Cluster Dynamics, Sweden.

Porter, M. E. (1998). Clusters and competition: New agendas for companies, governments, and institutions. In M. Porter (Ed.), On competition (pp. 197-287). Boston: Harvard Business School Press.

Porter, M. E. (2000). Location, Competition, and Economic Development: Local Clusters in a Global Economy. Economic Development Quarterly, 14(1), 15-34. https://doi.org/10.1177/089124240001400105

Province de Liège. Retrieved December, 2019 from http://www.provincedeliege.be

Raj, T., \& Attri, R. (2011). Identification and modeling of barriers in the implementation of TQM. International Journal of Productivity and Quality Management, 28(2), 153-179. https://doi.org/10.1504/IJPQM.2011.041844

Raj, T., Shankar, R., \& Suhaib, M. (2007). An ISM approach for modeling the enablers of flexible manufacturing system: The case for India. International Journal of Production Research, 46(24), 1-30.

Ravi, V., Shankar, R., \& Tiwari, M. K. (2005). Productivity improvement of a computer hardware supply chain. International Journal of Production and Performance Measurement, 54(4), 239-255. https://doi.org/10.1108/17410400510593802

Reid, A., \& Musyck, B. (2010). Industrial Policy in Wallonia: A Rupture with the Past? European Planning Studies, 8(2), 183-200. https://doi.org/10.1080/096543100110820

Rodrigue, J.-P., Comtois, C., \& Slack, B. (2006). The Geography of Transports Systems. Nova Yorque: Routledge.

Sage, A. P. (1977). Interpretive structural modeling: Methodology for large scale systems. New York, NY: McGraw-Hill.

Sartorio, K. (2004). Uma Ferramenta para Captura de Ontologias Baseadas na Técnica ISM. Dissertação de Mestrado - Universidade Estadual Paulista. Faculdade de Engenharia de Bauru.

Sheffi, Y. (2012). Logistics Clusters: Delivering Value and Driving Growth. The MIT Press.

Singh, M. D., Shankar, R., Narain, R., \& Agarwal, A. (2003). An interpretive structural modeling of knowledge management in engineering industries. Journal of Advances in Management Research, 1(1), 28-40. https://doi.org/10.1108/97279810380000356

STATBEL. (n.d.). Retrieved December, 2019 from https://statbel.fgov.be/fr

Warfield, J. W. (1974). Developing interconnected matrices in structural modeling. IEEE Transactions on Systems Men and Cybernetics, 4(1), 51-81. https://doi.org/10.1109/TSMC.1974.5408524

Watson, R. (1978). Interpretive Structural Modeling- A useful tool for worth assessment? Technological Forecasting and Social Change, 11, 165-185. https://doi.org/10.1016/0040-1625(78)90028-8

Wilmotte, P., \& Halleux, J. (2018). The Spatial Structure of Regional Innovation System: What about the Impact of Geographic Proximity within Walloon Competitiveness Clusters? Belin. L'Espace géographique, 47, 5170. https://doi.org/10.1016/0040-1625(78)90028-8

\section{Copyrights}

Copyright for this article is retained by the author(s), with first publication rights granted to the journal.

This is an open-access article distributed under the terms and conditions of the Creative Commons Attribution license (http://creativecommons.org/licenses/by/4.0/). 